\title{
EFEKTIVITAS METODE TUTOR SEBAYA DALAM MENINGKATKAN KEMAMPUAN NUMBER SENSE SISWA KELAS VII SMP NEGERI 1 DURIPOKU
}

\author{
Hermansyah $^{1}$, Irianto Aras ${ }^{2}$, Fitria Harun ${ }^{3}$ \\ ${ }^{1,2}$ Universitas Borneo Tarakan \\ ${ }^{3}$ SMP Negeri 1 Duripoku \\ h3rmansyah16@gmail.com , arasirianto1990@gmail.com², \\ fitriaharun535@gmail.com ${ }^{3}$
}

Received 21 November 2019; revised 6 July 2020; accepted 15 July 2020.

\begin{abstract}
ABSTRAK
Penelitian ini bertujuan untuk melihat efektivitas metode pembelajaran tutor sebaya dalam meningkatkan kemampuan number sense siswa di kelas VII A SMP Negeri 1 Duripoku. Penelitian ini merupakan penelitian pra-eksperimental dengan one group pre test-post design. Untuk melihat apakah terdapat perbedaan rata-rata kemampuan number sense sebelum dan sesudah diterapkan metode tutor sebaya, maka dilakukan uji paired sample t-test, sementara untuk melihat efektivitasnya dilakukan analisis gain ternomalisasi $(N$-Gain). Dari hasil analisis data pada taraf signifikansi 5\%, ditemui nilai $t=7.721$ dengan signifikansi $0,00(<0.05)$ yang berarti terdapat perbedaan nilai rata-rata kemampuan number sense pada pre test dan post test, untuk hasil analisis $\mathrm{N}$-Gain diperoleh bahwa efektivitas metode tutor sebaya dalam meningkatkan kemampuan number sense berada pada kategori rendah.
\end{abstract}

Kata kunci: efektivitas, number sense, tutor sebaya.

\begin{abstract}
This study aims to see the effectiveness of peer tutoring learning methods in improving the ability of number VII-A students of SMP Negeri 1 Duripoku. This research is a preexperimental study with one group pre-test - post design. To see whether there is a difference in the average number sense ability before and after the peer tutor method is applied, a paired sample t-test is performed. in analyzing its effectiveness, a normalized gain (N-Gain) analysis was performed. The result showed that the $t$-value was -7.721 with a significance of $0.00(<0.05)$, which means there is a significant difference mean score of number sense in pre-test and post-test. It indicated that the peer tutoring method's effectiveness in increasing the ability of number sense was in a low category.
\end{abstract}


Keywords: effectiveness, number sense, peer tutoring.

\section{PENDAHULUAN}

Matematika sebagai ilmu memiliki perbedaan dengan matematika yang diajarkan dijenjang persekolahan atau disebut matematika sekolah, hal ini dibedakan atas penyajiannya, pola pikirnya, keterbatasan semestanya, dan tingkat keabstrakannya (Soedjadi, 2000). Salah satu kesulitan mengajarkan matematika pada kelas awal jenjang Sekolah Menengah Pertama (SMP) adalah ketika siswa tidak punya dasar pengetahuan yang baik tentang matematika, ini sepenuhnya bergantung pada penguasaan siswa terhadap materi matematika ketika berada di Sekolah Dasar (SD) (Sari, 2019). Materi yang seharusnya dianggap selesai justru harus sering dibahas bahkan diulangi untuk memberikan kemampuan prasyarat sebelum mempelajari materi matematika di SMP, seperti pecahan, desimal, perkalian, bahkan tidak jarang tentang operasi pengurangan dan penjumlahan bilangan bulat.

Berdasarkan uji coba awal tentang pengetahuan bilangan pada peserta didik baru di kelas VII.A SMP Negeri 1 Duripoku, ditemui sebagian besar siswa kurang mampu mengurutkan bilangan negatif dari terkecil ke terbesar, kurang mampu mengidentifikasi bilangan mana yang lebih besar jika diekspresikan dalam bentuk desimal dan pecahan, kesalahan dalam melakukan operasi hitung campuran, kesalahan menyelesaikan operasi hitung dalam bentuk soal cerita, serta tidak mampu menghitung operasi yang memuat substitusi variabel dengan nilai tertentu. Dari berbagai kesalahan siswa tersebut, bisa disimpulkan bahwa umumnya siswa masih belum memiliki kompetensi yang cukup dalam mengenali dan mengoperasikan bilangan, hal ini berkaitan dengan number sense mereka. Number sense mengacu pada pemahaman umum seseorang tentang operasi yang disertai kemampuan dan kecenderungan untuk menggunakan pemahaman secara fleksibel dalam melakukan penilaian matematis, serta untuk mengembangkan strategi yang bermanfaat untuk menangani persoalan angka dan operasi (McIntosh, Reys, Reys, Bana, \& Farrel, 1997) (Widodo \& Noviartati, 2018).

Number sense dapat dilihat dari beberapa indikator diantaranya number concept, multiple representation, effect of operation, equivalent expression, serta 
computing and counting strategies (McIntosh, Reys, Reys, Bana, \& Farrel, 1997). Untuk mengembangkan kemampuan tersebut, maka diperlukan pola pembimbingan oleh guru secara mandiri bagi masing-masing siswa sebagai prasayat mempelajari materi matematika di SMP, sebab penguasaan suatu konsep ataupun keterampilan yang cenderung lemah sejak siswa di sekolah dasar akan berlanjut hingga ke sekolah menengah (Sabrianti, 2012). Oleh karena materi tersebut adalah prasyarat maka guru harus menggunakan metode yang tepat agar tidak menyita waktu pokok pembelajaran. Metode pembelajaran yang dimaksud adalah tutor sebaya (peer tutoring). Metode tutor sebaya adalah suatu metode pembelajaran yang dilakukan dengan cara memberdayakan siswa yang memiliki daya serap yang tinggi dari kelompok siswa itu sendiri untuk menjadi tutor bagi teman-temannya, dimana siswa yang menjadi tutor bertugas untuk memberikan materi belajar dan latihan kepada teman-temannya (tutee) yang belum paham (Arjanggi \& Suprihatin, 2011). Pembelajaran menggunakan tutor sebaya menurut Tsuei (2014) dapat meningkatkan kefasihan matematika pada masalah konseptual, begitupun penelitian dari Wardiyyah (2009) dan Nurmala, dkk (2016), menunjukkan metode tutor sebaya dapat meningkatkan hasil belajar konsep bilangan.

Dari acuan pemikiran itulah, maka dilakukan penelitian untuk melihat bagaimana efektivitas metode tutor sebaya dalam meningkatkan kemampuan number sense siswa kelas VII SMP Negeri 1 Duripoku, dengan tujuan untuk melihat bagaimana efektivitas metode pembelajaran tutor sebaya terhadap kemampuan number sense siswa.

\section{METODE PENELITIAN}

Jenis penelitian ini adalah pre-eksperimental dengan memberikan perlakuan pada satu kelompok/kelas saja tanpa ada kelas kontrol. Adapun sampel penelitian adalah kelas VII-A SMP Negeri 1 Duripoku yang dipilih secara random dari tiga kelas yang ada. Desain penelitian yang digunakan adalah one group pre test-post test design seperti pada Tabel 1 (Ary, Jacobs, \& Razavieh, 1982).

Tabel 1. One Group Pre Test-Post Test Design

\begin{tabular}{cccc}
\hline Group & Pre Test & Treatment & Post Test \\
\hline VII A & $\mathrm{O}_{1}$ & $\mathrm{X}$ & $\mathrm{O}_{2}$ \\
\hline
\end{tabular}


Keterangan:

$\mathrm{O}_{1}$ : Pre Test

$\mathrm{O}_{2}:$ Post Tes

$\mathrm{X}$ : Treatment (Perlakuan)

Untuk memperoleh data tentang kemampuan number sense siswa, dibuat instrument dengan memuat indikator number sense yaitu number concept, multiple representation, effect of operation, equivalent expression, serta computing and counting strategies. Data kemampuan number sense dianalisis menggunakan statistika deskriptif dan inferensial. Satatistika deskriptif digunakan untuk menghitung rata-rata dan simpangan baku perolehan tes kemampuan numbers sense siswa sebelum dan sesudah diterapkannya metode tutor sebaya. Sementara statistika inferensial digunakan untuk menguji hipotesis. Sebelum uji hipotesis, terlebih dahulu dilakukan uji normalitas data menggunakan KolmogrovSmirnov, jika diperoleh data berdistribusi normal untuk hasil pre-test dan post-test maka dilakukan uji rata-rata menggunakan paired sample $t$-test, namun jika tidak maka akan dilakukan analisis inferensial menggunakan statistik non parametrik. Adapun hipotesis yang akandiuji sebagai berikut,

Ho : Tidak terdapat perbedaan rata-rata hasil tes kemampuan number sense siswa sebelum dan setelah diterapkan metode pembelajaran tutor sebaya.

$\mathrm{H}_{1}$ : Terdapat perbedaan rata-rata hasil tes kemampuan numbers sense siswa sebelum dan setelah diterapkan metode pembelajaran tutor sebaya.

Pengambilan keputusan dari hipotesis yang diuji adalah jika nilai sig (2tailed) lebih kecil dari taraf signifikansi yang ditetapkan $(0,05)$ maka $\mathrm{H}_{0}$ ditolak dan $\mathrm{H}_{\mathrm{a}}$ diterima, begitupun sebaliknya jika nilai signifikansi lebih besar atau sama dengan 0,05 maka $\mathrm{H}_{0}$ diterima dan $\mathrm{H}_{\mathrm{a}}$ ditolak. Untuk melihat efektivitas metode tutor sebaya terhadap kemampuan number sense, maka dilakukan analisis perolehan (gain) yang ternormalisasi, adapun cara untuk memperoleh gain yang ternormalisasi menurut Hake (1999):

$$
<g>=\frac{\bar{x}_{\text {post }}-\bar{x}_{\text {pre }}}{100 \%-\bar{x}_{\text {pre }}}
$$

Keterangan:

$<g>: N$-Gain 
$\bar{x}_{\text {pre }} \quad$ : Rata-rata skor pretest

$\bar{x}_{\text {post }}:$ Rata-rata skor posttest

Setelah diperoleh nilai rata-rata $\mathrm{N}$-gain dari penerapan metode tutor sebaya, untuk melihat efektivitas perlakuan pada pembelajaran (course), maka nilai tersebut kemudian dikategorikan menjadi beberapa kriteria seperti pada Tabel 2 (Hake, 1998).

\begin{tabular}{cc}
\multicolumn{2}{c}{ Tabel 2. Kategori Rata-Rata $N$-Gain } \\
\hline Rata-rata $N$-Gain & Kategori \\
\hline$(<g>) \geq 0,7$ & Tinggi \\
$0,3 \leq(<g>)<0,7$ & Sedang \\
$(<g>)<0,3$ & Rendah \\
\hline
\end{tabular}

\section{HASIL PENELITIAN DAN PEMBAHASAN}

Pelaksanaan penelitian dimulai dengan memberikan pre test kemampuan number sense di pertemuan pertama. Pertemuan kedua dilakukan dengan melakukan pembelajaran menggunakan metode tutor sebaya dengan terlebih dahulu memberikan pengajaran secara langsung untuk seluruh siswa, memberikan bimbingan khusus kepada siswa yang akan diberi amanah menjadi tutor, serta mengarahkan tutor yang telah dibimbing untuk memberikan pemaparan kepada teman kelompoknya seperti pada Gambar 1. Pola kegiatan pembelajaran pembimbingan oleh teman sebaya dilakukan sebanyak tiga kali pertemuan. Supaya tidak mengganggu aktivitas pembelajaran materi inti, maka pembelajaran dilakukan sore hari setelah jam pelajaran sekolah selesai.
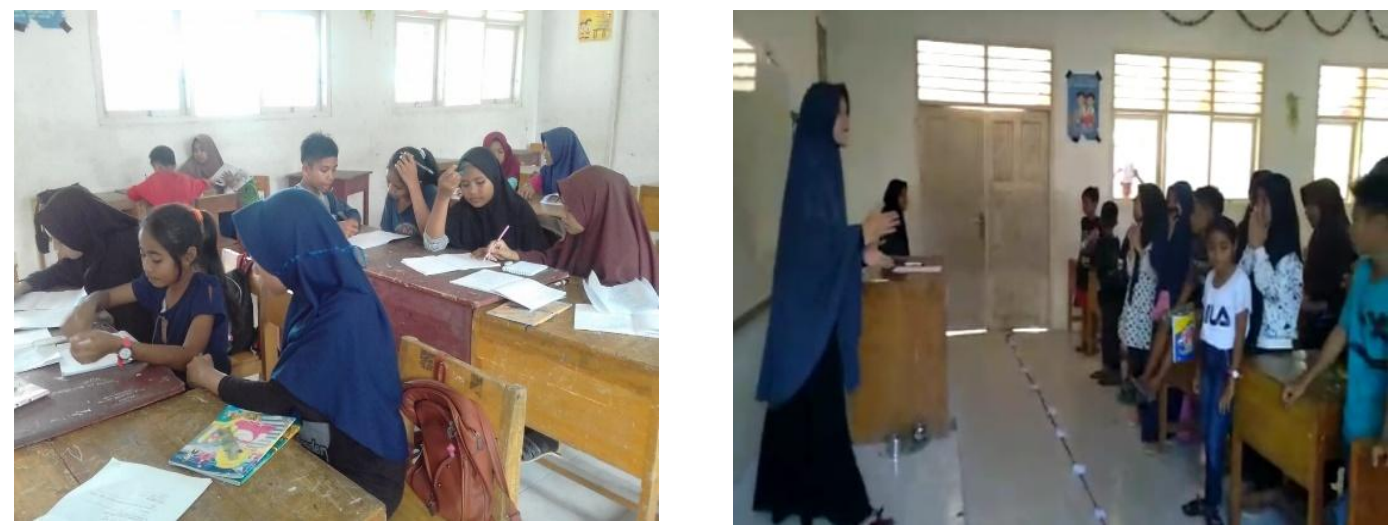

Gambar 1. Pembelajaran Menggunakan Metode Tutor Sebaya 
Setelah seluruh rangkaian kegiatan pembelajaran dilaksanakan selama tiga kali pertemuan menggunakan metode tutor sebaya, berikutnya dilakukan evaluasi akhir (post test) untuk melihat kemampuan number sense siswa setelah diberikan perlakuan menggunakan metode pembelajaran tutor sebaya.

\section{Hasil Tes Kemampuan Number Sense}

Pelaksanaan tes kemampuan number sense dilakukan sebanyak dua kali, yaitu sebelum dan sesudah diterapkannya metode tutor sebaya. Adapun rata-rata dan simpangan baku dari hasil pre test dan post test disajikan pada Tabel 3.

Tabel 3. Rata-Rata Hasil Pre Test dan Post Test

\begin{tabular}{cccc}
\hline & JumlahSampel & Rata-Rata & Simpangan Baku \\
\hline Pretest & 28 & 65,09 & 7,80 \\
Posttest & 28 & 72,27 & 10,45 \\
\hline
\end{tabular}

Ringkasan hasil tes kemampuan number sense tersebut menunjukkan bahwa rata-rata hasil pre test adalah 65,09 dengan simpangan baku 7,80, sedangkan untuk post test adalah 72,27 dengan simpangan baku 10,45 dari jumlah sampel sebanyak 28. Hasil tersebut menunjukkan bahwa secara deskriptif ada perbedaan rata-rata hasil kemampuan number sense sebelum dan setelah siswa diajari menggunakan metode tutor sebaya. Namun demikian, perlu dilihat apakah perbedaan tersebut signifikan terjadi karena penerapan metode tutor sebaya, atau hanya kebetulan belaka, untuk itu dilakukan pengujian hipotesis menggunakan uji-t sampel berpasangan (independent sample t-test) dengan terlebih dahulu melihat normalitas datanya.

\section{Uji Normalitas}

Uji normalitas dilakukan untuk melihat apakah data yang diperoleh berasal dari populasi yang berdistribusi normal atau tidak, adapun data hasil analisis untuk hasil pre test dan post test diberikan pada Tabel 4. Hasil uji normalitas dengan signifikansi 5\% memberikan kesimpulan bahwa untuk pre test signifikansinya adalah 0,165 (> 0,05$)$ yang berarti data yang diperoleh berdistribusi normal, sementara untuk post test signifikansinya adalah 0,118 $(>0,05)$ berarti juga berdistribusi normal. 
Tabel 4. Hasil Uji Normalitas

\begin{tabular}{cccc}
\hline & Statistic & $\boldsymbol{d f}$ & Sig. \\
\hline Pretest & 0,141 & 28 & 0,165 \\
Posttest & 0,220 & 28 & 0,118 \\
\hline
\end{tabular}

\section{Uji-t Sampel Berpasangan}

Uji sampel berpasangan (independent sample t-test) dilakukan untuk mengetahui apakah terdapat perbedaan kemampuan number sense sebelum dan sesudah diterapkannya metode tutor sebaya di kelas VII-A SMP Negeri 1 Duripoku. Dalam artian ingin diketahui apakah perbedaan rata-rata yang terjadi setelah diterapkannya metode tutor sebaya itu nyata atau hanya kebetulan belaka. Hasil perhitungan nilai t uji sampel berpasangan disajikan pada Tabel 5.

Tabel 5. Hasil Uji-t Sampel Berpasangan

\begin{tabular}{ccccc}
\hline & Stand. Error mean & $\boldsymbol{t}$ & $\boldsymbol{d} \boldsymbol{f}$ & Sig.(2 tailed) \\
\hline Paired & 0,92993 & $-7,721$ & 27 & 0,000 \\
\hline
\end{tabular}

Berdasarkan Tabel 5 diperoleh bahwa hasil analisis menggunakan paired sample $t$-test diperoleh nilai $t=-7,721$ dan signifikansi 0,000 . Pengambilan keputusan adalah jika signifikansi lebih kecil dari 0,05 maka yang diterima adalah hipotesis altenatif $\left(\mathrm{H}_{1}\right)$ dan menolak hipotesis nol $\left(\mathrm{H}_{0}\right)$, dengan demikian dapat disimpulkan bahwa terdapat perbedaan rata-rata kemampuan number sense siswa kelas VII-A sebelum dan sesudah penerapan metode tutor sebaya dalam pembelajaran.

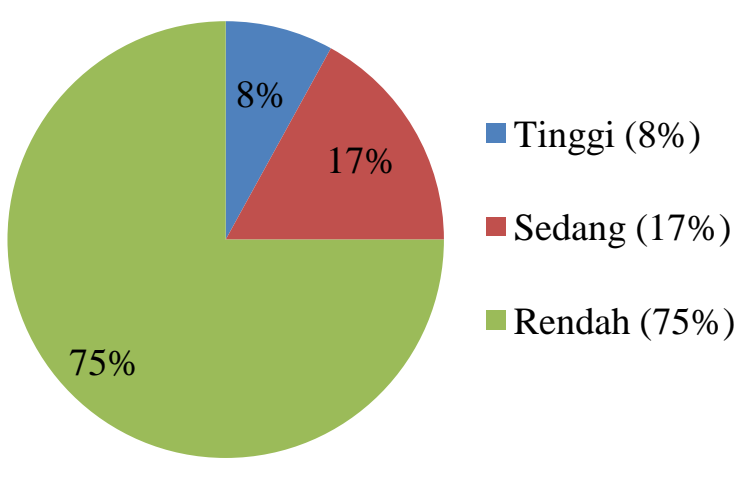

Gambar 3. N-Gain Kemampuan Number Sense Siswa 


\section{Analisis $N$-Gain}

Dari hasil uji-t sampel berpasangan diperoleh bahwa terdapat perbedaan rata-rata kemampuan number sense sebelum dan sesudah diterapkannya metode tutor sebaya, karena terdapat perbedaan maka untuk melihat efektivitas metode tutor sebaya dilakukan analisis $N$-Gain, hasil analisis gain untuk kemampuan number sense masing-masing siswa dapat dilihat pada Gambar 3.

Dari hasil analisis $N$-Gain terhadap 28 siswa, sebanyak 2 siswa yang berada dalam kategori tinggi, 4 orang siswa berada pada kategori sedang, dan 21 orang siswa pada kategori rendah. Untuk efektitvitas masing-masing indikator dari kemampuan number sense berada pada kategori rendah seperti pada Tabel 6 .

Tabel 6. Hasil Analisis N-Gain terhadap Indikator Number Sense

\begin{tabular}{cccccc}
\hline $\begin{array}{c}\text { Number } \\
\text { Sense }\end{array}$ & $\begin{array}{c}\text { Number } \\
\text { Concept }\end{array}$ & $\begin{array}{c}\text { Multiple } \\
\text { representation }\end{array}$ & $\begin{array}{c}\text { Effect of } \\
\text { operation }\end{array}$ & $\begin{array}{c}\text { Equivalent } \\
\text { expression }\end{array}$ & $\begin{array}{c}\text { Computingand } \\
\text { CountingStrategies }\end{array}$ \\
\hline Pre Test & 67,7 & 57,5 & 52,5 & 66,66 & 67,22 \\
Post Test & 77,2 & 66,94 & 61,66 & 69,58 & 68,33 \\
N-Gain & 0,30 & 0,22 & 0,19 & 0,087 & 0,033 \\
Kategori & Sedang & Rendah & Rendah & Rendah & Rendah \\
\hline
\end{tabular}

Tabel 6 menunjukkan bahwa efektivitas metode tutor sebaya untuk masing-masing indikator number sense berada pada kategori sedang dan rendah. Untuk melihat efektivitas metode tutor sebaya terhadap kemampuan number sense pada kelas VII-A maka dilakukan perhitungan rata-rata $N$-Gain, dengan rata-rata pre-test sama dengan 65,09 dan post-test sama dengan 72,27. Dengan menggunakan rumus analisis perolehan (gain) ternormalisasi diperoleh,

$$
<g>=\frac{72,27-65,09}{100-65,09}=0,205
$$

Hasil rata-rata gain ternormalisasi adalah 0,205 yang menunjukkan bahwa efektivitas penerapan metode tutor sebaya dalam meningkatkan kemampuan number sense berada pada kategori rendah.

Berdasarkan hasil penelitian diperoleh bahwa ada perbedaan rata-rata kemampuan number sense siswa kelas VII-A sebelum dan sesudah diterapkannya metode tutor sebaya, sementara keefektivan pembelajaran yang dilihat dari analisis rata-rata $\mathrm{N}$-Gain berada pada kategori rendah. Itu berarti efektivitas metode tutor sebaya dalam penelitian ini tidak memberikan dampak yang besar 
bagi kemampuan number sense siswa. Dari semua indikator number sense, hanya indikator number concept yang berada pada kategori sedang, sementara untuk indikator lainnya berada pada kategori rendah.

Number concept berkaitan dengan pengetahuan konseptual siswa, beberapa penelitian tentang penerapan metode tutor sebaya seperti penelitian Wardiyyah (2009) dan Nurmala, dkk (2016), menunjukkan metode tutor sebaya dapat meningkatkan hasil belajar konsep bilangan. Ini cukup rasional bahwa pengajaran konsep bilangan oleh teman tutor bisa memberikan pemahaman yang lebih baik dengan penjelasan bahasa keseharian mereka. Untuk efektivitas metode tutor sebaya terhadap indikator lain dalam number sense yaitu multiple representation, effect of operation, equivalent expression, serta computing and counting strategies berada pada kategori rendah, indikator ini menuntut siswa untuk memahami konsep bilangan dan membuat hubungan dalam memecahkan masalah, sehingga siswa yang ditunjuk menjadi tutor kesulitan memahami dan menjelaskan kepada tutee, meski pada dasarnya tutor yang ditunjuk itu berkemampuan tinggi. Hal ini diperkuat oleh penelitian Safitri, dkk (2017) yang menemukan bahwa siswa dengan kategori kemampuan tinggi kurang peka terhadap operasi dan hubungan antar operasi hitung bilangan bulat beserta sifat-sifatnya dalam memecahkan masalah.

Secara umum beberapa penelitian tentang number sense juga menemukan hal yang serupa, penelitian Acoi (2011) dan Sabrianti (2012) menyebutkan bahwa potensi dan kemampuan number sense siswa di kelas VII tergolong rendah. Halini diduga karena penguasaan suatu konsep ataupun keterampilan yang cenderung lemah sejak siswa di sekolah dasar akan berlanjut hingga ke sekolah menengah. Untuk itu, meski metode tutor sebaya memiliki efektivitas rendah dalam meningkatkan kemampuan number sense, setidaknya bisa menjadi suatu solusi dalam mengatasi kesulitan siswa dalam mempelajari materi pembelajaran di Sekolah Menengah Pertama.

Penelitian ini memiliki keterbatasan, yakni pelaksanaan pembelajaran menggunakan metode tutor sebaya hanya sebanyak tiga kali pertemuan, sehingga peneliti tidak mengetahui apakah pola pembimbingan yang dilakukan antara siswa dengan temannya. Selain itu, selama proses penelitian berlangsung peneliti tidak 
menyiapkan lembar observasi terhadap perilaku siswa yang mungkin timbul dari penerapan metode tutor sebaya, seperti ketidaksesuaian antara tutee dan teman tutor yang mungkin ditunjukkan oleh perilaku mereka pada saat berinteraksi. Aspek lain yang menjadi keterbatasan adalah tidak adanya penelitian pembanding yang pernah menghubungkan antara metode tutor sebaya dan kemampuan number sense.

\section{SIMPULAN}

Berdasarkan perolehan data dan hasil analisis yang dilakukan, maka diperoleh kesimpulan bahwa terdapat perbedaan rata-rata kemampuan number sense Siswa kelas VII-A SMP Negeri 1 Duripoku sebelum dan sesudah proses belajar menggunakan metode pembelajaran tutor sebaya. Efektivitas metode tutor sebaya dalam meningkatkan kemampuan number sense siswa berada pada kategori rendah. Saran yang dapat peneliti berikan adalah kesulitan siswa dalam mempelajari materi matematika banyak disebabkan oleh materi prasyarat di tingkat sekolah dasar terutama menyangkut masalah kepekaan terhadap bilangan, untuk itu perlu dilakukan pembelajaran tambahan tentang materi prasyarat dengan memanfaatkan teman mereka sebagai tutor. Meski dalam penelitian ini metode tutor sebaya memiliki efektivitas yang rendah, namun bisa dilakukan perbaikan dengan mempertimbangkan keterbatasan-keterbatasan yang ada dalam penelitian ini.

\section{DAFTAR PUSTAKA}

Acoi, P. (2011). Deskripsi number sense siswa kelas VII SMP santo fransiskus asisi Pontianak. Surabaya: Universitas Negeri Surabaya.

Arjanggi, S., \& Suprihatin, T. (2011). Metode pembelajaran tutor teman sebaya meningkatkan hasil belajar berdasar regulasi-diri. Hubs-Asia , 10 (1), 9197.

Ary, D., Jacobs, L. C., \& Razavieh, A. (1982). Pengantar penelitian dalam pendidikan. Surabaya: Usaha Nasional.

Hake, R. R. (1998). Interactive-engagement versus traditional methods: A sixthousand-student survey of mechanics test data for introductory physics courses. American Journal of Physics, 66(1), 64-74.

Hake, R. R. (1999). Analyzing change/gain scores. AREA-D American Education Research Association's Devision. D. USA: Measurement and Reasearch Methodology. 
McIntosh, A., Reys, B., Reys, R., Bana, J., \& Farrel, B. (1997). Number sense in school mathematics: student performance in four countries. Perth: Mathematics, Science \& Technology Education Centre, Edith Cowan University.

Nurmala, N., Sukayasa, S., \& Paloloang, B. (2016). Penerapan model pembelajaran tutor sebaya untuk meningkatkan hasil belajar siswa kelas $\mathrm{V}$ SDN 20 Toli-Toli pada operasi hitung campuran bilangan bulat. Jurnal Kreatif Tadulako Online, 4(9), 199-211.

Sabrianti, R. (2012). Potensi number sense siswa pada materi penjumlahan pecahan biasa di madrasah tsanawiyah. Surabaya: Universitas Negeri Surabaya.

Safitri, A. S., Mulyati, S., \& Chandra, T. D. (2017). Kemampuan number sense siswa sekolah menengah pertama (SMP) kelas VII pada materi bilangan. In Prosiding SI MaNIs (Seminar Nasional Integrasi Matematika dan NilaiNilai Islami) (Vol.1, No.1, pp. 270-277).

Sari, R. K. (2019). Analisis problematika pembelajaran matematika di Sekolah Menengah Pertama dan solusi alternatifnya. Prismatika: Jurnal Pendidikan dan Riset Matematika , 2 (1), 23-31.

Soedjadi, R. (2000). Kiat pendidikan matematika di Indonesia (konstatasi keadaan masa kini menuju harapan masa depan). Jakarta: Dirjen Dikti Departemen Pendidikan Nasional.

Tsuei, M. (2014). Mathematics synchronous peer tutoring system for students with learning disabilities. Journal of Educational Technology \& Society, 17(1), 115-127.

Wardiyyah, N. (2009). Penerapan model pembelajaran tutor sebaya untuk meningkatkan hasil belajar peserta didik kelas VII MTs NU Banat Kudus pada materi pokok operasi bilangan pecahan semester I tahun ajaran 2009/2010. Semarang: IAIN Walisongo.

Widodo, A., \& Noviartati, K. (2018). Profil number sense siswa SMP terhadap pecahan campuran ditinjau dari kepribadian introvert. Jurnal Pi, Pend. Mat. STKIPH , 1 (2), 44-51. 